\title{
CSR or ISO Certification: What Does Really Matter for Consumer in Developing Countries
}

\author{
Ammar Ahmad ${ }^{*}$ \\ Muhammad Azeem² \\ Sanober Salman Shaikh ${ }^{3}$
}

\begin{abstract}
This empirical study was aimed to discover the impact of corporate social responsibility (CSR) and international standardization of organization (ISO) on corporate reputation (CR) and corporate reputation's effect on consumer loyalty (CL). In addition, the relationship of corporate reputation $\&$ trust (T), corporate reputation with consumer company identification (CCI) was also examined. Lastly the association of consumer company identification, trust and consumer loyalty (CL) was also analyzed. The data was collected from 500 students of three different universities and survey instrument was administrated. Overall, eight hypotheses were examined to confirm the relationship among variables by using the CFA (Confirmatory Factor Analysis) and structural equation modeling (SEM) was used to test the validity of the instrument with the help of AMOS and SPSS software.

The resultindicated that ISO and environmental CSR has direct relationship with corporate reputation. Corporate reputation had direct association with trust. Whereas, corporate reputation was significantly positive related with consumer company identification. Subsequently, Trust also showed positive relation with loyalty and positive relationship was found between consumer company identification and consumer loyalty. Furthermore, results showed that community development- corporate social responsibility had no relationship with corporate reputation and corporate reputation was significantly related with customer loyalty. The findings of this study contribute in the literature provided instrument authenticity and adaptability in Pakistani context. In this study limitations and future recommendations were also provided.
\end{abstract}

Keywords:CSR, ISO, Consumer Company Identification, Corporate Reputation, Trust, Consumer Loyalty.

1. Assistant Professor, Department of Business Administration, ISP, Multan, email: ammar. malik419@gmail.com

2. Ph.D. Scholar, Universiti Utara Malaysia, email: azeeminpk@gmail.com

3. Institute of Business Administration, University of Sindh Jamshoro, Pakistan, email: sanobershaikh25@yahoo.com 
IBT Journal of Business Studies Volume 15(1), 2019

\section{INTRODUCTION}

The Fast-Moving Consumer Goods (FMCG) refers to products or goods which can be consumed wholly or in part over a short period of time e.g. a few days, weeks, months, within a year of purchase (Moolla \& Bisschoff, 2012). The core focus of the FMCG firm's marketing activities is to develop, maintain and enhance the customer's loyalty towards its marketed products or services (Ngobo, 2017). Therefore, increasing unpredictability, product differentiation and highly competitive pressure have increased the importance of customer loyalty in the FMCG marketplace.

According to Economist (2013) FMCG firms have a scope of growth in Pakistan. Pakistan Economic Survey (2017) revealed a significant growth of 9.65 percent in the FMCG industry of Pakistan. The main reason of growth of FMCG in Pakistan is its growing population and major portion belongs to middle-class consumers (Economist, 2013). In Pakistan, various multinational and national FMCG firms are operating and heavily invested in its production and distribution (Ahmed et al., 2017). Current academic researches and the market polls proposes that consumers of now a day shows a great interest for those companies who are making a fruitful difference in the world. Corporate social responsibility is one of the preference of consumers globally (Becker-Olsen et al., 2011; Schmeltz, 2012). Wang (2011) stated that attachment of consumer with a firm is another key issue for corporate sector. Consumer bonding can be observed with a firm by giving quality products and remove consumer problems related to products. Bonding of the firm with a consumer became the reason of giving birth to other multiple elements such as consumer loyalty and trust along. Along with all this another picture starts developing in the mind of consumer which is known as corporate reputation.

It is a general perception of today's consumer that the firms with ISO certification provide quality products. Nair and Prajogo (2009) concluded that the objectives of manufacturing companies adopting the ISO as a means for giving credible gestures to external stakeholders. ISO in real is not considers as an alternate to total quality management (TQM) but it accompaniments it. Chittenden et al. (1998-99) posited that UK based organizations are more expanded, developed multi-product and adopted ISO standards. ISO certification and having no expansion deals with targeted local customers. Wiengarten et al. (2017) found that implementing ISO standards directly helpful in improving the results in organizations in the terms of coordination among the departments, increased consumer loyalty, improved production, reduced cost, increased sales and better control of the business. Moreover, Calderon (2011) defined engagement of corporation in society is known as corporate social responsibility (CSR). The multiple organizations, researchers and government officers have paid adequate attention to CSR (Newman et al., 2018). Social responsibility is an individual's responsibility to examine the effect of his/her decisions and actions on entire social system (Davis \& Blomstorm, 1996). Consequently, the objective of this study is to examine the effect of ISO certification and CSR activities on customer loyalty through the mediating role of corporate reputation, trust and consumer company identification in the Pakistan. market.

\section{LITERATURE REVIEW}

The following section review the pertinent literature on the study's variables and relationship among them.

\section{Corporate Social Responsibility}

The actual definition of corporate social responsibility is hard to find because different researchers have explained the CSR in their own views. Mohr et al. (2001) contribution has a substantial 
position in the following literature related to corporate social responsibility (CSR) explanation and classification (Mandhachitara \& Poolthong, 2011). By adding to this, two major categories have explored named as, environmental CSR and community development CSR. But environmental CSR has been a prime concentration of many researches (Pedersen, 2010; Williamson et al., 2006; Mohr \& Webb, 2005) to its clear-cut feasibility and validity in business operations. Cheung et al. (2009) specified that applying environmental CSR is not only a benefit to manufacturers, but it also could be positive for service provider with internal drivers like meeting the corporate environment policy or environmental guidelines and with external drivers such as to identify a positive corporate image and their status. Peloza and Shang, (2011) revealed that the service provider's reputation can be enhanced by a successful environmental CSR.

Furthermore, environmental corporate social responsibility has a high acceptability by both customers and the media as well as easy to understand (Rahbar \& Wahid, 2011). Environmental CSR and CSR in general has too many differences, if we talk about environmental CSR, it includes the activities with respect to environment such as green production, pollution elimination, energy conservation whereas, CSR activities in general include the activities that shows concern for the society like contributions in public welfare, philanthropy, sustainable development.Similarly, with respect to stakeholders CSR activities have totally different meaning, it includes fair treatment with employees, returns on investments, monitoring, development and influencing supplier's behavior. In short, it means organizations should obligated to all stakeholders not only shareholders.

The effects of environmental CSR on the perceptions of consumers is explained well by the previous researchers.Groening, Sarkis and Zhu (2018) demonstrated the strong liking of consumers in purchasing from more ecologically friendly lifestyle of organizations who adopts friendly environmental practices. The owners and manufacturers who seriously undertakes the initiative of environmental CSR surely gets positive feedback in the purchases and evaluation of organizations (Mohr \& Webb, 2005). Likewise, Ahmed and Malik (2016) found the positive impact of CSR on the customer satisfaction, and customer satisfaction leads to the customer loyalty. Marin and Ruiz (2007) explored the positive relationship between customer liking and attraction for a bank who cares about CSR activities. Association between customer satisfaction and corporate social responsibility was resulted in company's environmentally friendly image and it had positive impact on satisfied customer (Chen, 2010). Corporate social responsibility is a burning topic in management and academic concern (Peloza \& Shang, 2011), specially its association with consumer behaviors. Modern consumer started employing CSR image of company in buying and consuming patterns (Choi \& $\mathrm{Ng}$, 2011). Orlitzky, Schmidt and Rynes (2003)observed that environmental corporate responsibility always creates positive reputation which leads to high performance.Scholars and researchers have been studying concern for society for many eras (Choi \& Ng, 2011).Aguinis (2011) defined the CSR as context-specific organizational actions and policies that consider stakeholders' expectations and the triple bottom line of economic, social, and environmental performance. Peloza (2009) engrossed in finding the CSR's impact on financial performance, Wood (2010) focused on how to create great value for stakeholders with the help of CSR. In addition, other researches of CSR have explained the CSR into other different disciplines like human resource management, operations (Brammer, Hoejmose \& Millington, 2011), marketing (Enderle \& Murphy, 2009), psychology (Aguinis, 2011), organizational behavior and information system (Elliot, 2011).In short, the explanation of corporate social responsibility defines the steps, actions and policies of organizations and those policies and actions are executed by others at all the levels of an organization such as individual, organizational and institutional. 
IBT Journal of Business Studies Volume 15(1), 2019

\section{International Standardization of Organization (ISO)}

The impact of ISO accreditation on organizational performance has been widely studied subject among the researchers and revealed mixed findings. According to Benner and Veloso (2008), the ISO accreditation is greatly structured practices to develop an organizational system which comprises on the working quality from all aspects within the organization. Moreover, effect of ISO certification on the organizational performance was determined and it was found that organizations those implementing the ISO standards can generate more profits than those of without ISO organizations (Benner \& Veloso, 2008). Impact of ISO on organizational performance was examined through two viewpoints. Firstly, the performance improvement was evaluated through the efficiencies in the organizational operations that directly resulted into the cost reduction (Corbettetal., 2005). Secondly, the performance was evaluated in terms of the increment in the revenues of the organization because the ISO certification and adoption of the ISO standards led the organization into the new markets and attracts new customers (Terlaak \& King, 2006; Corbettal., 2005). Quazi and Padibjo (1998) examined the relation of quality management with ISO. They directed that ISO accreditation work as an incremental approach towards the quality management practices. Nevertheless, scholars claimed that ISO certifications provides several benefits to the organizations. Simultaneously, organizations face numerous challenges and barrier in order to maintain these certifications. Sila (2018) stated that different ISO certifications and practices enhances different organizational activities like work approaches, employee empowerment, workforce management, employee involvement, employee satisfaction, workforce commitment, staff training and development, human resource management and compensation practices which improves the working quality as well as operational performance of the organization. The reason behind the adoption of the ISO standards is to improve the internal processes which lead towards the enhancement of operational performance as well as financial performance. These ISO certifications helps in the development of corporate reputation and customer trust (Singhetal., 2010). Singh et al. (2010), explored that organizations always strives for having better internal processes which urge them to adopt ISO standards and enhancing the organizations in their internal operations which ultimately helps in increasing the organizational profitability.

Past studies also confirmed that the ISO certifications positively contribute in the customer satisfaction which ultimately develop corporate reputation in the customer's minds and finally makes them loyal customers. Hence, the focus of this study is to determine the effect of ISO on corporate reputation and its impact on customer loyalty.

\section{Consumer Loyalty}

Scholars defined the loyalty with multiple ways. This concept is conceptualized with customer loyalty towards companies, brands and stores (Ahmed \& Malik, 2016). A person's attitude towards and affection for a brand is known as loyalty. The research conducted on organizational identification specifies that if customers start identifying their selves with an organization they start purchasing more often and also suggest the company's services and products more than before (Ahearne, Bhattacharya \& Gruen 2005; He \& Li, 2011). Consumer loyalty can be well-defined as the approach and association established by consumer for seller of product/services. The connection between buyer and seller is established on long- standing collaboration, stability and acceptance of services offered by them (Harris, 2010). Past studies also signify the benefits of loyal customers to the organization. Schiffman and Kanuk (2010) described that loyal customer always remains attached with single brand or single organization. Likewise, customer satisfaction is the influentialconcept that gives birth to loyalty. It is a multi-dimensional concept which is operationalized and defined in multiple ways in the literature of marketing (Blythe, 1997). Similarly, Oliver (1997) explains the three parameters of satisfaction called conative, cognitive and affective. Although there are number 
of studies have been taken on customer loyalty but it has mostly been studied from two perspectives attitudinal loyalty and behavioral loyalty (e.g. Dick \& Basu, 1994; Nam et al., 2011). The frequency of repetition in purchases is known as behavioral purchases whereas, the psychological commitment by the consumer in purchasing activities is called attitudinal loyalty for example purchase intentions (Ahmed \& Othman, 2016). Several researches have been conducted on loyalty (Gefen \& Straub, 2003). Loyalty is very important these days for any kind of interactions as it can be with clients or customers (Dasgupta, 1988). Bowen and Shoemaker (2003) highlighted the significance of creating relationships on the basis of commitment and trust.

\section{Hypothesis Development}

Keeping in view the past literature, the following hypothesis were developed.

H1: International Standardization of Organization (ISO) has a direct relationship with Corporate Reputation.

H2: Environmental Corporate Social Responsibility has a direct relationship with Corporate Reputation.

H3: Community Development - Corporate Social Responsibility (CSRCD) has a direct relationship with Corporate Reputation.

H4: Corporate Reputation has direct relation with Trust.

H5:Corporate reputation has a direct relationship with Consumer Company Identification.

H6: Corporate Reputation has a direct relationship with Customer Loyalty.

H7: Trust has a direct relationship with Customer Loyalty.

H8: Consumer Company Identification has a direct relationship with Consumer Loyalty.

\section{METHODOLOGY}

This study used quantitative research approach in which Survey method was adopted to collect the data.

\section{Population and Sample}

The consumers were the unit of analysis for this study. Therefore, students of three different universities were selected; they are youth and consumers of FMCG products. Today's youth is very much well aware about the products to consume, firms to buy and qualities to maintain, in fact students keep an eye on every firm reputation and their image in the market. The universities taken in this study are Punjab University, COMSATS University and University of Lahore. According to higher education commission (HEC), these universities are considered big universities of Pakistan. Total 500 questionnaire were distributed through convenience sampling and 404 respondents responded to the questionnaires.

\section{Measurements}

Questionnaire was categorized in two parts: first part covered the details about demographic characteristics of respondents and second part included the multiple items on study's key variables. On International standardization Organization variable, the respondents were asked only whether they know that chosen organization is ISO certified or not. The environmental corporate social responsibility variable of this study includes 4-items, adopted from (Mael \& Ashforth, 1995). The community development corporate social responsibility variable includes 3-items, adopted from (Mael \& Ashforth, 1995). Corporate reputation variable includes 3-items, taken from (Weiss et al., 1999). Trust variable includes 3-items, selected from (Pivato et al., 2009). Another variable, consumer company identification includes 3-items, adopted from (Sen \& Bhattacharya, 2006). The 
IBT Journal of Business Studies Volume 15(1), 2019

consumer loyalty includes 3-items adopted from (Pivato et al., 2009). All items were measured on 7-point Likert scale.

\section{Data Collection Procedure}

The survey instrument was administrated to obtain the data from survey respondents. Initially the questionnaire was pre-tested, it was assessed by the four professors of different departments having research expertise. Then pilot study was conducted through collecting data from 30 consumers and scale reliability was also evaluated. Thereafter, the complete data was collected from 500 respondents.

\section{PROPOSED DATA ANALYSIS AND RESULTS}

Under analysis, SPSS and AMOS software were used to generate the results. The convergent validity, discriminant validity was assessed and then the hypothetical model was examined through SEM (CFA) technique.

\section{Missing Value Analysis}

The data was entered in the SPSS and missing values were identified. Out of 404 respondents, no missing value was found.

\section{Demographic Characteristics of the Sample}

The demographic characteristics of the 404-sample revealed that 161 (39.9\%) respondents were female and $243(60.1 \%)$ respondents were male. 328 respondents $(81.2 \%)$ were under the age group of (16-25 years), 41 (10.1\%) belong to the age group of (26-35 years), While, only $1(0.2 \%)$ belongs to the age group of (36-45 years) and 34 (8.4\%) students belong to the age group of (upto-50 years). Under the education distribution pattern, 15 (3.71\%) respondents enrolled in $\mathrm{Ph}$. D program, 47 (11.6\%) enrolled in M. Phil program, 243 (60.1\%) enrolled in graduate programs and 99 (24.5\%) were enrolled in post-graduate programs. Furthermore, occupation distribution of the sample depicts that $11(2.7 \%)$ of the respondents were running business, $5(1.2 \%)$ were government employees, while $8(2 \%)$ were households. Only $13(3.2 \%)$ were attached with the private sector and majority of the respondents $367(90.8 \%)$ were students.

\section{Normality Test}

To test the normality of data the Kolmogorove-Smirnove Statistical test was used, the results found that the P-value of all variables are under 0.00 which depicts data is not normally distributed.

\section{Reliability}

Reliability test was also applied to check the validity of the research instruments. It is shown in table 1, the values of CSRE, CSRCD, CR, Trust, CL and CCI are 0.69, 0.79, 0.76, 0.80, 0.71 and 0.75 respectively. Each construct shows the good reliability because the reliability values of these variables are more than 0.7 and near to 0.7 . Hence, it was found suitable and reliable constructs to further analyze for CFA and SEM analysis.

\section{Confirmatory Factor Analysis}

This study adopted the confirmatory factor analysis (CFA) and evaluated the validity of latent constructs. 6 latent constructs and 1 observational item are used in CFA analysis. The result shows the suitability of all model. Two conditions were need to be fulfilled in CFA analysis after checking the observational items and latent constructs. First condition is to consider that free parameters 
should be less than or equal to number of observations. Secondly is to check that there must have a scale for the measurement error and factor of latent constructs (Kline \& Seffah, 2005). By applying such analysis, convergent as well as discriminant validity was found and model fitness was also verified. Figure 2 shows the covariances of the latent constructs (CFA).

\section{Convergent Validity and Discriminant Validity}

In convergent validity, the average variance extracted (AVE) value were evaluated of each latent construct. Table 2 and 3 depicts the convergent validity and discriminant validity of the latent constructs. While examining convergent validity, the AVE value results of environmental - CSR is 0.36 ; it shows lower than the cut-off value of 0.5 . This result also exhibits the lower value than it's correlation of squared roots. Thus, it does not show any discriminant validity problem. Furthermore, the AVE value of community development-CSR is 0.32 , it is also lower than 0.5 . In addition, the community development-CSR AVE value is also less than from its all squared root correlations. Hence, it was observed that there is no issue of discriminant validity.

Further, the AVE value of corporate reputation is 0.51 this is higher than 0.5 . It is assumed that corporate reputation with three items holds convergent validity in context of Pakistan. Corporate reputation AVE is higher than correlation of squared root. Therefore, it shows discriminant validity. Similarly, the AVE value of trust is 0.58 , it was found greater than 0.5 it explained that with 3 items in trust construct has also convergent validity in Pakistan. In addition the results also depicts that AVE of trust is greater than from its all squared root relation. Thus, this construct has discriminate validity.

The AVE value of customer loyalty is 0.45 it also seems lower than 0.5 , it represents that consumer loyalty along with 3- items does not have convergent validity. Besides it AVE value of consumer loyalty is less than from its all squared root correlations. Hence, it also does not hold discriminant validity. Lastly, the consumer company identification AVE value of 0.38 is lower than 0.5 which illustrate that the CCI with its 3-items has no convergent validity in Pakistan context. Moreover, the AVE of CCI is less than from its all squared rootcorrelations. Consequently, ithas no any discriminant validity.

\section{Conceptual Model Testing}

In this paper, SEM technique were employed to test the conceptual model. AMOS software was used applied to test the model which also shown in figure 2. It explains the acceptability of indexes by showing the values of NFI, TLI, RMSEA, and AGFI. The table 4 shows the fit indexes of the current model. The value of GFI, Normed Chi- square and Bolans IFI are showing that the model has good fit. Also, AGFI, RMSEA, TLI, NFI values show acceptable indexes fit. Therefore, it can be concluded that model is good position and clearly describes the relationship among all variables of the study.

\section{Hypothesis Testing}

The hypothesis was tested and the standardized regression weights are shown in table 5, the beta coefficient value of CSRE is 0.328 at 0.005 significant value which results that CSRE has a direct relationship with CR because significant value is lower than 0.05 . The beta coefficient value of ISO is 0.160 at 0.02 significant value which results that ISO has a direct relationship with CR because significant value is lower than 0.05 . The beta coefficient value of CSRCD is 0.171 at 0.144 significant value which results that CSRE has a negative relationship with CR because the significant value is same as lower than 0.05 , but the P-value is higher. 
The beta coefficient value of $\mathrm{CR}$ is 0.408 at 0.00 significant value, it is resulted that $\mathrm{CR}$ has positive relationship with CCI because significant value is lower than 0.05 . The beta coefficient value of CR is 0.739 at 0.00 significant value which is also less than 0.05 which depicts the positive relationship between $\mathrm{CR}$ and trust. The beta coefficient value of CR is 0.006 at 0.950 insignificant value, the significant value is again smaller than 0.05 but in this case the P-value is higher than 0.05 which shows negative relationship between CR with customer loyalty. The beta coefficient value of trust is 0.443 at 0.00 significant value resulted the positive relationship of trust and customer loyalty because significant value is less than 0.05 . The beta coefficient value of CCI is 0.388 at 0.00 significant value which also explains the positivity among CCI and customer loyalty because the significant value is less than 0.05 .

Hence, this study framed the eight hypotheses, out of eight, two hypotheses (H3 \& H6) were rejected and six hypotheses (H1, H2, H4, H5, H7 \& H8) were accepted. See table 6.

\section{DISCUSSION}

This paper examined the influence of ISO and CSR on consumer loyalty through the mediating role of corporate reputation in the Pakistani FMCG context, also examined the mediating role of Consumer Company Identification and Trust in order to improve consumer loyalty. In this study it was observed that ISO as an independent variable and CR as a mediating variable shows positive relation between them. According to result analysis, beta coefficient value of 0.160 at 0.02 significant value. The other purpose of this study was to check the relationship of ISO on consumer loyalty with mediation effect of corporate reputation. Environmental-CSR has positive connection with CR. By comparing this variable with others, it has shown more significance because all other values are either insignificant or less significant like shown in the results the beta coefficient value of ECSR is 0.328 , significant at 0.005 . If significant value is less than 0.05 , it means there is positive relationship among these variables.

Significant value is less than 0.05 which shows the positive relationship among these. As comparative to all other variables CSRE is highly correlated. Therefore, it strongly creates corporate reputation more than ISO and CSRCD. The results also indicate no effect of community development-CSR on corporate reputation. The result shows 0.171 beta coefficient value at 0.144 insignificant P-value. Therefore, it reflects the insignificant relation with CR. CR builds Trust and results are the witnessed of this statement that the beta coefficient is 0.739 , at 0.00 significant values, which is also 0.05 and display positive relation among corporate reputation and trust. The development of consumer company identification is important to create a perception in customer's mind which is known as corporate reputation. This paper has resulted the positive relationship among corporate reputation and consumer company identification with a There is no direct beta co-efficient results of 0.408 significant at 0.00 value, which is less than 0.05 . There is no direct relationship between corporate reputation and consumer loyalty was found in this study. Previous literature also resulted the same findings and showed that the 0.006 beta coefficient value at 0.950 insignificant value, where the significant value is greater than 0.05 . Therefore, it is clear now that corporate reputation did not directly affects the customer loyalty, it only works with a mediating role of consumer company identification and trust which ultimately influences consumer loyalty. The beta coefficient value of trust and consumer company identification which is 0.443 and 0.388 at 0.00 significant value have also shown the positive link between trust and consumer company identification with consumer loyalty which is also proved by the P-value. Therefore, there is a need that FMCG firms should focus on its quality standards and other social responsibilities which can help in the development 
of corporate reputation, customer trust customer strong relation with firms and mainly customer loyalty (Ahmed et al., 2017).

\section{Theoretical and Managerial Implications}

In pertinent literature, several studies examined the association among corporate social responsibility, loyalty of customer, and ISO. These constructs were rarely examined in single research framework. This study contributed theoretically in the literature by identifying the impact of both constructs (CSR, ISO) on customer loyalty. In addition, the role of corporate reputation, consumer company identification and trust were examined as mediators between these relationships.

Furthermore, previous studies have investigated the relationship between corporate reputation and customer loyalty in different work settings of different countries. While, this study examined the said relationship in the developing country context like Pakistan and found the insignificant relationship between CR and CL. In addition, there were two mediating variables like trust and consumer company identification were also examine between CR and CL relationship. Its add value in the pertinent literature that the CR develops the customer loyalty through the CCI and trust especially in the developing countries context. It was also examined that CSR activities has positive and strong relation with CR relatively than ISO, in fact ISO has significant relationship with CR.

When relationship of CSR: CSR-E and CSR-CD were examine with CR, the finding revealed that the CSR-E has positive relationship with CR, whereas, CSR-CD has insignificant relationship with CR. CSR-CD did not contribute in the development of CR. Therefore, these findings theoretically contribute in the literature which brings new insights in front of the future researchers, scholars and management alike. Similarly, this study will also have managerial implications as it may help business managers, business development managers, and executive managers for the better understanding of the business practices.

\section{CONCLUSION, LIMITATIONS AND FUTURE RECOMMENDATIONS}

As research trend is getting importance in Pakistan, this study was conducted according to Pakistani scenario. These findings of the study positively add value in the pertinent literature related to each variable studied especially in the developing country context. According to the findings, it can be observed that ISO and E-CSR are extremely advantageous for the organizations in order to make their customers loyal because these two variables helps to create a corporate reputation in the mind of consumers with mediating effects of consumer company identification and trust. Therefore, Pakistani organizational should consider the importance of all the above mentionedvariables.

Limitations related to the time and cost, the sample for the present study was limited to the three universities. Therefore, it could be potentially tested with a larger sample in the same industry so the future analysis is recommended for using the multiple industry samples. Yet, it is highly advised to the future researchers and business consultants to evaluate the CSR and ISO impact in developing the brand loyalty in the Pakistan Retail market or FMCG sector. Furthermore, it is recommended to adopt qualitative approach to determine the experiences of the frequent customers.

\section{REFERENCES}

Aggarwal, P. (2004). The effects of brand relationship norms on consumer attitudes and behavior. Journal of Consumer Research, 31(1), 87-101.

Aguinis, H. (2011). Organizational responsibility: Doing good and doing well. APA handbook of 
IBT Journal of Business Studies Volume 15(1), 2019

industrial and Organizational Psychology, 3, 855-879.

Ahearne, M., Bhattacharya, C. B., \& Gruen, T. (2005). Antecedents and consequences of customercompany identification: Expanding the role of relationship marketing. Journal of Applied Psychology, 90(3), 574.

Ahmed, A., \& Malik, M. S. (2016). Strategy to Customer Loyalty: Building CSR and Service Quality: LAP LAMBERT. Academic Publishing Germany.

Ahmed, A., \& Othman, I. L. (2016). Mediating Role of Customer Commitment on Customer Loyalty in FMCG. Scholars Journal of Economics, Business and Management, 3(5), 263-270.

Ahmed, A., Khuwaja, F. M., Othman, I. B. L., Qureshi, M. A., \& Ali, R. A. (2017). Validation of SERVQUAL Model in Relation to Customer Loyalty: Evidence from FMCGs in Pakistan. Sukkur IBA Journal of Management and Business, 4(2), 54-76.

Andreassen, T. W., \&Lindestad, B. (1998). The effect of corporate image in the formation of customer loyalty. Journal of Service Research, 1(1), 82-92.

Barich, H., \& Kotler, P. (1991). A framework for marketing image management. MIT Sloan Management Review, 32(2), 94.

Becker-Olsen, K. L., Taylor, C. R., Hill, R. P., \&Yalcinkaya, G. (2011). A cross-cultural examination of corporate social responsibility marketing communications in Mexico and the United States: Strategies for global brands. Journal of International Marketing, 19(2), 30-44.

Benner, M. J., \& Veloso, F. M. (2008). ISO 9000 practices and financial performance: A technology coherence perspective. Journal of Operations Management, 26(5), 611-629.

Bergami, M., \&Bagozzi, R. P. (2000). Self-categorization, affective commitment and group selfesteem as distinct aspects of social identity in the organization. British Journal of Social Psychology, 39(4), 555-577.

Bhattacharya, C. B., \&Elsbach, K. D. (2002). Us versus them: The roles of organizational identification and disidentification in social marketing initiatives. Journal of Public Policy \& Marketing, 21(1), 26-36.

Blythe, J. (1997). The essence of consumer behavior. Pearson: PTR.

Bowen, J. T., \& Shoemaker, S. (2003). Loyalty: A strategic commitment. Cornell Hotel and Restaurant Administration Quarterly, 44(5-6), 31-46.

Brammer, S., Hoejmose, S., \& Millington, A. (2011). Managing sustainable global supply chain: framework and best practices.

Brewer, M. B. (1991). The social self: On being the same and different at the same time. Personality and Social Psychology Bulletin, 17(5), 475-482.

Calderon, M. (2011). CSR in Latin America and South East Asia analysis of the corporate communication of top local companies. International Research Journal of Finance and Economics, 73, 56-74.

Chen, Y., \& Pearcy, J. (2010). Dynamic pricing: when to entice brand switching and when to reward consumer loyalty. The RAND Journal of Economics, 41(4), 674-685.

Cheung, D. K., Welford, R. J., \& Hills, P. R. (2009). CSR and the environment: business supply chain partnerships in Hong Kong and PRDR, China. Corporate Social Responsibility and Environmental Management, 16(5), 250-263

Choi, S., \& Ng, A. (2011). Environmental and economic dimensions of sustainability and price effects on consumer responses. Journal of Business Ethics, 104(2), 269-282.

Liang, J., Moore, R. E., Moher, E. D., Munroe, J. E., Al-awar, R. S., Hay, D. A., ... \& Shih, C. (2005). Cryptophycins-309, 249 and other cryptophycin analogs: preclinical efficacy studies with mouse and human tumors. Investigational New Drugs, 23(3), 213.

Delgado-Ballester, E., Munuera-Aleman, J. L., \&Yague-Guillen, M. J. (2003). Development and validation of a brand trust scale. International Journal of Market Research, 45(1), 35-54.

Page | 104 
Davis, K., \&Blomstrom, R. L. (1966). Business and its environment. McGraw-Hill.

Dick, A. S., \&Basu, K. (1994). Customer loyalty: toward an integrated conceptual framework. Journal of the Academy of Marketing Science, 22(2), 99-113.

Dutton, J. E., Dukerich, J. M., \&Harquail, C. V. (1994). Organizational images and member identification. Administrative Science Quarterly, 239-263.

Economist, T. (2013). Consumer goods.Retrieved from:

http://www.eiu.com/industry/article/141041398/pakistan-fmcgs-provide-an-economic-brightspot/2013-10-09

Baumann, C., Elliott, G., \&Hamin, H. (2011). Modelling customer loyalty in financial services: a hybrid of formative and reflective constructs. International Journal of Bank Marketing, 29(3), 247-267.

Enderle, G., \& Murphy, P. E. (2009). Ethics and corporate social responsibility for marketing in the global marketplace. The SAGE Handbook of International Marketing, 504-531.

Fombrun, C. J., \& Van Riel, C. B. M. (2003). Fame \& fortune: How the world's top companies develop winning reputations. Pearson Education.

Groening, C., Sarkis, J., \& Zhu, Q. (2018). Green marketing consumer-level theory review: A compendium of applied theories and further research directions. Journal of Cleaner Production, $172,1848-1866$.

Harris, L. C., \& Goode, M. M. (2010). Online servicescapes, trust, and purchase intentions. Journal of Services Marketing, 24(3), 230-243.

He, H., \& Li, Y. (2011). CSR and service brand: The mediating effect of brand identification and moderating effect of service quality. Journal of Business Ethics, 100(4), 673-688.

Hwang, J., \& Wen, L. (2009). The effect of perceived fairness toward hotel overbooking and compensation practices on customer loyalty. International Journal of Contemporary Hospitality Management, 21(6), 659-675.

Kline, R. B., \&Seffah, A. (2005). Evaluation of integrated software development environments: Challenges and results from three empirical studies. International Journal of Human-Computer Studies, 63(6), 607-627.

Mael, F., \&Ashforth, B. E. (1992). Alumni and their alma mater: A partial test of the reformulated model of organizational identification. Journal of Organizational Behavior, 13(2), 103-123.

Mael, F. A., \&Ashforth, B. E. (1995). Loyal from day one: Biodata, organizational identification, and turnover among newcomers. Personnel psychology, 48(2), 309-333.

Mandhachitara, R., \&Poolthong, Y. (2011). A model of customer loyalty and corporate social responsibility. Journal of Services Marketing, 25(2), 122-133.

Marin, L., \& Ruiz, S. (2007). "I need you too!" Corporate identity attractiveness for consumers and the role of social responsibility. Journal of Business Ethics, 71(3), 245-260.

Mohr, L. A., \& Webb, D. J. (2005). The effects of corporate social responsibility and price on consumer responses. Journal of Consumer Affairs, 39(1), 121-147.

Mohr, L. A., Webb, D. J., \& Harris, K. E. (2001). Do consumers expect companies to be socially responsible? The impact of corporate social responsibility on buying behavior. Journal of Consumer Affairs, 35(1), 45-72.

Moolla, A. I., \&Bisschoff, C. A. (2012). Validating a model to measure the brand loyalty of fast moving consumer goods. Journal of Social Sciences, 31(2), 101-115.

Nair, A., \&Prajogo, D. (2009). Internalization of ISO 9000 standards: the antecedent role of functionalist and institutionalist drivers and performance implications. International Journal of Production Research, 47(16), 4545-4568.

Nam, J., Ekinci, Y., \&Whyatt, G. (2011). Brand equity, brand loyalty and consumer satisfaction. Annals of Tourism Research, 38(3), 1009-1030. 
IBT Journal of Business Studies Volume 15(1), 2019

Newman, C., Rand, J., Tarp, F., \&Trifkovic, N. (2018). The transmission of socially responsible behaviour through international trade. European Economic Review, 101, 250-267.

Ngobo, P. V. (2017). The trajectory of customer loyalty: an empirical test of Dick and Basu's loyalty framework. Journal of the Academy of Marketing Science, 45(2), 229-250.

Ogba, I. E., \& Tan, Z. (2009). Exploring the impact of brand image on customer loyalty and commitment in China. Journal of Technology Management in China, 4(2), 132-144.

Oliver, R. L., Rust, R. T., \& Varki, S. (1997). Customer delight: foundations, findings, and managerial insight. Journal of Retailing, 73(3), 311-336.

Orlitzky, M., Schmidt, F. L., \&Rynes, S. L. (2003). Corporate social and financial performance: A meta-analysis. Organization Studies, 24(3), 403-441.

Pedersen, E. R. (2010). Modelling CSR: How managers understand the responsibilities of business towards society. Journal of Business Ethics, 91(2), 155-166.

Peloza, J., \& Shang, J. (2011). How can corporate social responsibility activities create value for stakeholders? A systematic review. Journal of the academy of Marketing Science, 39(1), 117135.

Peloza, J. (2009). The challenge of measuring financial impacts from investments in corporate social performance. Journal of Management, 35(6), 1518-1541.

Perrini, F., Castaldo, S., Misani, N., \&Tencati, A. (2010). The impact of corporate social responsibility associations on trust in organic products marketed by mainstream retailers: a study of Italian consumers. Business Strategy and the Environment, 19(8), 512-526.

Parker, A. H., Youlten, R., Dillon, M., Nussbaumer, T., Carter, R. C., Tyrrel, S. F., \& Webster, J. (2010). An assessment of microbiological water quality of six water source categories in northeast Uganda. Journal of Water and Health, 8(3), 550-560.

Quazi, H. A., \&Padibjo, S. R. (1998). A journey toward total quality management through ISO 9000 certification-a study on small-and medium-sized enterprises in Singapore. International Journal of Quality \& Reliability Management, 15(5), 489-508.

Rahbar, E., \& Abdul Wahid, N. (2011). Investigation of green marketing tools' effect on consumers' purchase behavior. Business Strategy Series, 12(2), 73-83.

Roberts, P. W., \& Dowling, G. R. (2002). Corporate reputation and sustained superior financial performance. Strategic Management Journal, 23(12), 1077-1093.

Rose, C., \& Thomsen, S. (2004). The Impact of Corporate Reputation on Performance: Some Danish Evidence. European Management Journal, 22(2), 201-210.

Schiffman, L. G., \&Kanuk, L. L. (2010). Consumer Behavior. Edisi 10.

Schmeltz, L. (2012). Consumer-oriented CSR communication: focusing on ability or morality? Corporate Communications: An International Journal, 17(1), 29-49.

Sen, S., Bhattacharya, C. B., \&Korschun, D. (2006). The role of corporate social responsibility in strengthening multiple stakeholder relationships: A field experiment. Journal of the Academy of Marketing Science, 34(2), 158-166.

Sila, I. (2018). Linking Quality with Social and Financial Performance: A Contextual, Ethics-Based Approach. Production and Operations Management.

Singh, A., Pant, D., Korres, N. E., Nizami, A. S., Prasad, S., \& Murphy, J. D. (2010). Key issues in life cycle assessment of ethanol production from lignocellulosic biomass: challenges and perspectives. Bioresource Technology, 101(13), 5003-5012.

Smidts, A., Pruyn, A. T. H., \& Van Riel, C. B. (2001). The impact of employee communication and perceived external prestige on organizational identification. Academy of Management journal, 44(5), 1051-1062.

Survey, P. E. (2017). Overview of the Economy, Pakistan Economic Survey. Pakistan: Retrieved from: http://www.finance.gov.pk/survey/chapters_17/overview_2016-17.pdf. 
Tajfel, H., \& Turner, J. C. (1985). The psychology of intergroup relations (pp. 7-24). Chicago: Nelson-Hall. Google Scholar.

Terlaak, A., \& King, A. A. (2006). The effect of certification with the ISO 9000 Quality Management Standard: A signaling approach. Journal of Economic Behavior \& Organization, 60(4), 579602.

Walsh, G., \&Wiedmann, K. P. (2004). A conceptualization of corporate reputation in Germany: An evaluation and extension of the RQ. Corporate Reputation Review, 6(4), 304-312.

Wang, A., \& Anderson, R. B. (2011). A multi-staged model of consumer responses to CSR communications. The Journal of Corporate Citizenship, (41), 51.

Weiss, H. M., Suckow, K., \&Cropanzano, R. (1999). Effects of justice conditions on discrete emotions. Journal of Applied Psychology, 84(5), 786.

Whetten, D. A., \& Godfrey, P. C. (1998). (Eds.). Identity in organizations: Building theory through conversations. Sage.

Wiengarten, F., Humphreys, P., Onofrei, G., \&Fynes, B. (2017). The adoption of multiple certification standards: perceived performance implications of quality, environmental and health \& safety certifications. Production Planning \& Control, 28(2), 131-141.

Williamson, D., Lynch-Wood, G., \& Ramsay, J. (2006). Drivers of environmental behavior in manufacturing SMEs and the implications for CSR. Journal of Business Ethics, 67(3), 317-330.

Wood, D. J. (2010). Measuring corporate social performance: A review. International Journal of Management Reviews, 12(1), 50-84.

\section{Appendix A}

Theoretical Framework of the study

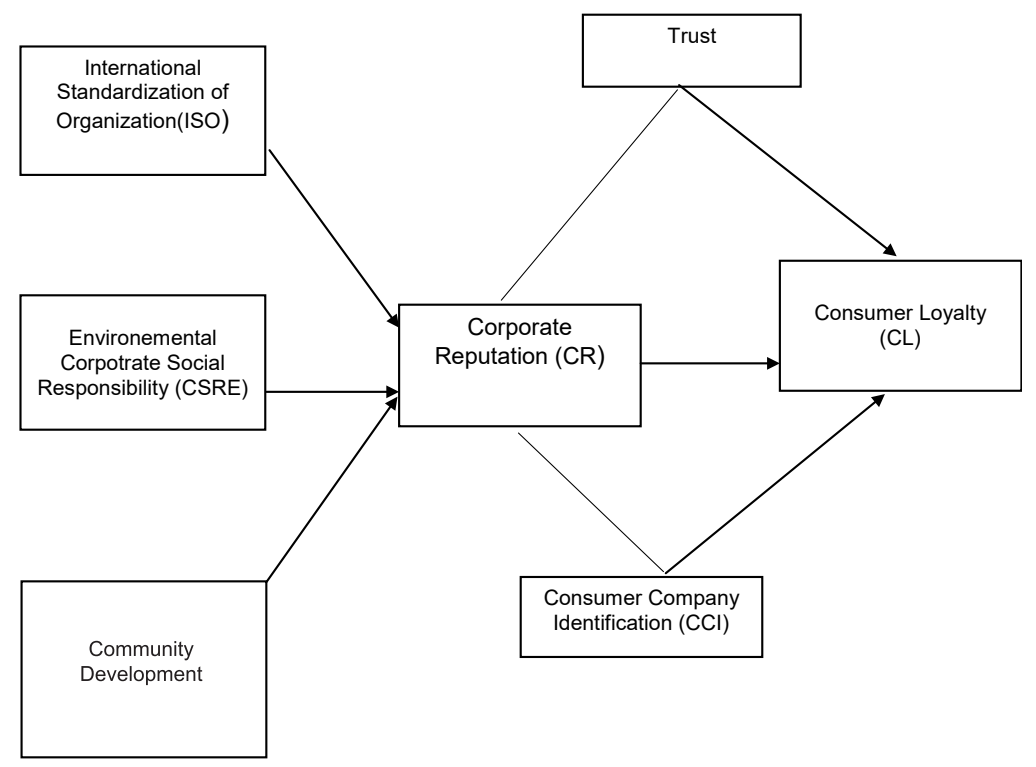

Figure 1

Theoretical Framework 
IBT Journal of Business Studies Volume 15(1), 2019

\section{Appendix B}

Table 1

Reliability Results

\begin{tabular}{|l|l|}
\hline Latent Construct & Reliability (Joreskog Rho) \\
\hline CSRE & 0.69 \\
\hline CSRCD & 0.79 \\
\hline CR & 0.76 \\
\hline Trust & 0.80 \\
\hline CL & 0.71 \\
\hline CCI & 0.75 \\
\hline
\end{tabular}

Appendix C

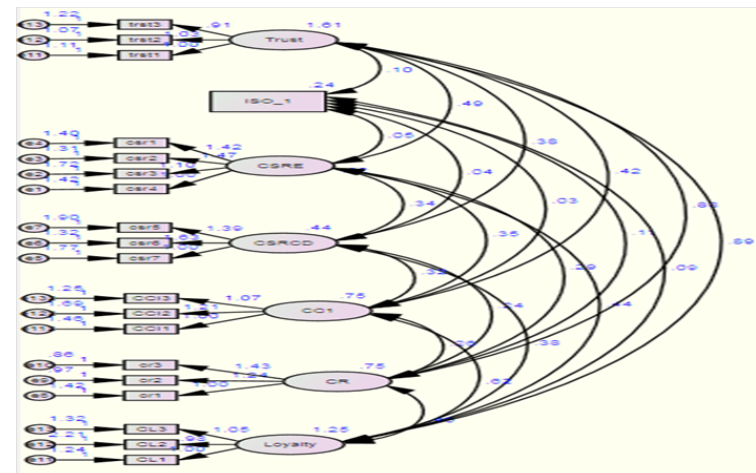

Figure 2

Confirmatory Factor Analysis

\section{Appendix D}

Table 2

Convergent Validity

\begin{tabular}{|l|l|}
\hline Latent Construct & Convergent Validity Rho ve \\
\hline CSRE & 0.36 \\
\hline CSRCD & 0.32 \\
\hline CR & 0.51 \\
\hline Trsut & 0.58 \\
\hline Loyalty & 0.45 \\
\hline CCI & 0.38 \\
\hline
\end{tabular}


Table 3

Discriminant Validity

\begin{tabular}{|l|l|l|l|l|l|l|}
\hline & CCI & CSRE & CS RCD & CR & Loyalty & Trust \\
\hline CCI & $\mathbf{0 . 3 8 0}$ & & & & & \\
\hline CSRE & 0.320 & $\mathbf{0 . 3 6 0}$ & & & & \\
\hline CSRCD & 0.309 & 0.505 & $\mathbf{0 . 3 2 0}$ & & & \\
\hline CR & 0.120 & 0.210 & 0.170 & $\mathbf{0 . 5 1 0}$ & & \\
\hline Loyalty & 0.407 & 0.302 & 0.257 & 0.222 & $\mathbf{0 . 4 5 0}$ & \\
\hline Trust & 0.140 & 0.290 & 0.207 & 0.635 & 0.397 & $\mathbf{0 . 5 8 0}$ \\
\hline
\end{tabular}

\section{Appendix F}

Table 4

Model Fit Indices

\begin{tabular}{|c|c|c|c|c|}
\hline \multicolumn{5}{|c|}{ Fitnessof the Model } \\
\hline $\begin{array}{l}\text { Type of Fit } \\
\text { Index }\end{array}$ & Fit Index & Calculated Value & $\begin{array}{c}\text { Recommended } \\
\text { Value }\end{array}$ & Remarks \\
\hline $\begin{array}{l}\text { Absolute Fit } \\
\text { Measures }\end{array}$ & Good offit index & .91 & $\begin{array}{l}\text { Higher values } \\
\text { consider better fit } \\
\text { nearto } 1 \text { goodfit }\end{array}$ & Fit \\
\hline \multirow[t]{2}{*}{ Measures } & $\begin{array}{l}\text { Adjust goodnes- } \\
\text { soffit }\end{array}$ & .88 & $\begin{array}{l}\text { Recommended } \\
\text { level }>=0.90\end{array}$ & $\begin{array}{l}\text { Acceptable } \\
\text { Fit }\end{array}$ \\
\hline & $\begin{array}{l}\text { Root Mean } \\
\text { Square } \\
\text { Error of Approxi- } \\
\text { mation (RMSEA) }\end{array}$ & 0.06 & $\begin{array}{l}\text { Acceptable } \\
\text { between } 0.01 \text { and } \\
0.05\end{array}$ & $\begin{array}{l}\text { Acceptable } \\
\text { Fit }\end{array}$ \\
\hline \multirow[t]{3}{*}{ Incremental } & $\begin{array}{l}\text { Tuker-Lewis } \\
\text { Index }\end{array}$ & $\begin{array}{l}\text { Recommended } \\
\text { level }>=0.90\end{array}$ & & $\begin{array}{l}\text { Acceptable } \\
\text { Fit }\end{array}$ \\
\hline & BolansIFI & .89 & $\begin{array}{l}\text { Suggested level > } \\
=0.90\end{array}$ & Fit \\
\hline & $\begin{array}{l}\text { Normed Fit } \\
\text { Index }\end{array}$ & .83 & $\begin{array}{l}\text { Recommended } \\
\text { level }>=0.90\end{array}$ & $\begin{array}{l}\text { Acceptable } \\
\text { Fit }\end{array}$ \\
\hline $\begin{array}{l}\text { Parsimonious Fit } \\
\text { Measures }\end{array}$ & $\begin{array}{l}\text { Normed Chi- } \\
\text { Square }\end{array}$ & 2.53 & $\begin{array}{l}\text { Recommended } \\
\text { levelb/w1.0and } \\
5.0 \text { betteriflow. }\end{array}$ & Fit \\
\hline
\end{tabular}


IBT Journal of Business Studies Volume 15(1), 2019

Appendix G

Figure 3

Conceptual Model Testing

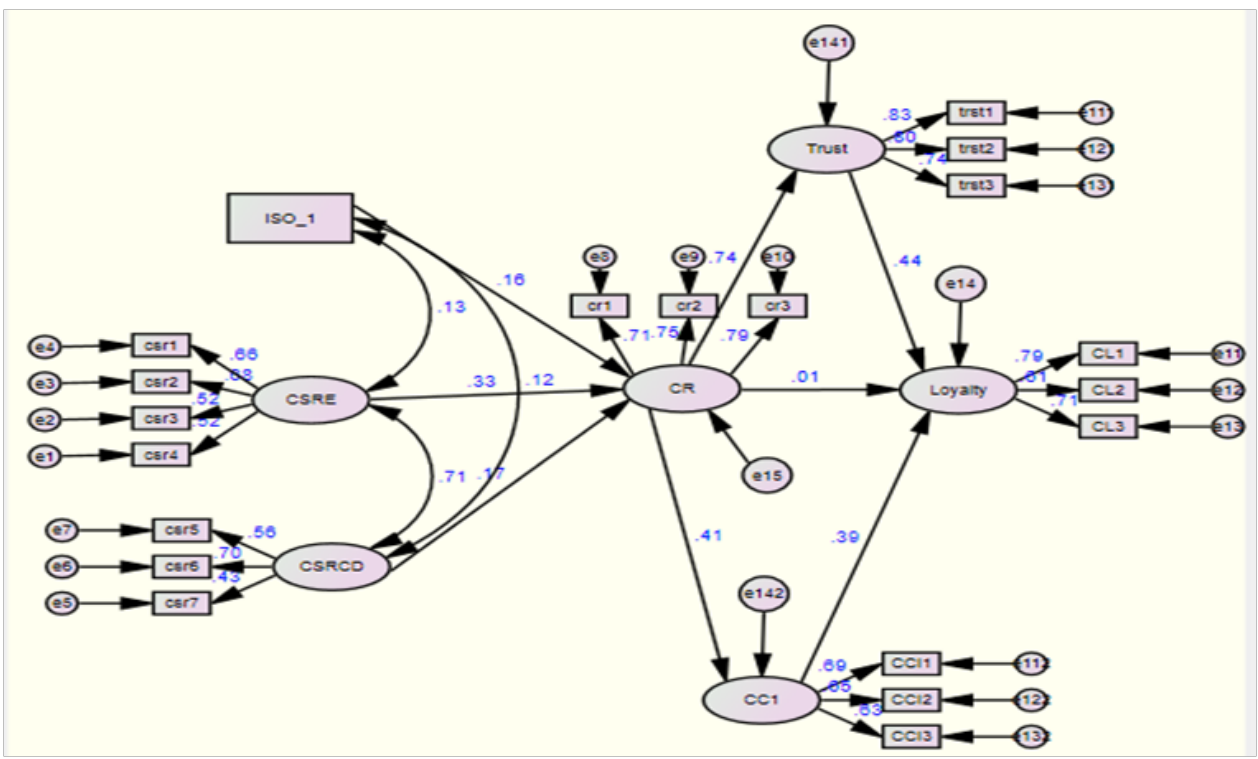

Appendix $\mathbf{H}$

Table 5

Standardized Regression Weights

\begin{tabular}{|c|c|c|c|c|c|c|c|}
\hline & & & Estimate & S.E. & C.R. & $\mathbf{P}$ & Label \\
\hline CR & $<---$ & CSRE & .328 & .188 & 2.818 & .005 & \\
\hline CR & $<---$ & $\mathrm{ISO}_{-} 1$ & .160 & .120 & 3.154 & .002 & \\
\hline CR & $<---$ & CSRCD & .171 & .215 & 1.461 & .144 & \\
\hline $\mathrm{CCl}_{1}$ & $<---$ & CR & .408 & .062 & 6.190 & $* * *$ & \\
\hline Trust & $<---$ & CR & .739 & .072 & 13.099 & $* * *$ & \\
\hline
\end{tabular}




\section{Appendix I}

Table 6

Hypothesis Summary

\begin{tabular}{|l|l|}
\hline Hypothesis & Decision \\
\hline $\begin{array}{l}\text { H1: International Standardization of Organization (ISO) has a direct } \\
\text { relationship with Corporate Reputation. }\end{array}$ & Accepted \\
\hline $\begin{array}{l}\text { H2: Environmental Corporate Social Responsibility (CSRE) has a direct } \\
\text { relationship with Corporate Reputation. }\end{array}$ & Accepted \\
\hline $\begin{array}{l}\text { H3: Community Development - Corporate Social Responsibility (CSRCD) } \\
\text { has a direct relationship with Corporate Reputation. }\end{array}$ & Rejected \\
\hline H4: Corporate Reputation has a direct relationship with Trust. & Accepted \\
\hline $\begin{array}{l}\text { H5: Corporate Reputation has a direct relationship with Consumer } \\
\text { Company Identification. }\end{array}$ & Accepted \\
\hline H6: Corporate Reputation has a direct relationship with Customer Loyalty. & Rejected \\
\hline H7: Trust has a direct relationship with Customer Loyalty. & Accepted \\
\hline $\begin{array}{l}\text { H8: Consumer Company Identification has a direct relationship with } \\
\text { Consumer Loyalty. }\end{array}$ & Accepted \\
\hline
\end{tabular}

\begin{tabular}{|ll|llll|}
\hline Loyalty <--- & CR & .006 & .116 & .062 & .950 \\
Loyalty <--- Trust & .443 & .086 & 4.684 & $* * *$ \\
Loyalty <--- CC1 & .388 & .083 & 5.752 & $* * *$ \\
\hline
\end{tabular}

